\title{
Marine biodiversity of a pristine coral reef in French Polynesia
}

\author{
David Lecchini
}

PSL University, EPHE-UPVD-CNRS, USR 3278 CRIOBE, 98729 Moorea, French Polynesia Laboratoire d'Excellence "CORAIL", Perpignan, France

david.lecchini@ephe.psl.eu (corresponding author; equal contribution as first author)

\section{Frédéric Bertucci}

Unité FRE BOREA, MNHN, CNRS 7208, Sorbonne University, IRD 207, University Caen Normandy, University of French West Indies, Guadeloupe

Functional and Evolutionary Morphology Lab, University of Liège, Belgium

fred.bertucci@gmail.com (equal contribution as first author)

\section{Lily Fogg}

Queensland Brain Institute, University of Queensland, Brisbane, Australia

\section{lily.fogg@uq.net.au}

\section{Camille Gache}

PSL University, EPHE-UPVD-CNRS, USR 3278 CRIOBE, 98729 Moorea, French Polynesia Laboratoire d'Excellence "CORAIL", Perpignan, France

gachecamille@hotmail.fr

Pascal Ung

PSL University, EPHE-UPVD-CNRS, USR 3278 CRIOBE, 98729 Moorea, French Polynesia Laboratoire d'Excellence "CORAIL", Perpignan, France

pascal.ung@criobe.pf

\section{Yann Lacube}

PSL University, EPHE-UPVD-CNRS, USR 3278 CRIOBE, 98729 Moorea, French Polynesia Laboratoire d'Excellence "CORAIL", Perpignan, France

yann.lacube@gmail.com

\section{Cecile Berthe}

PSL University, EPHE-UPVD-CNRS, USR 3278 CRIOBE, 98729 Moorea, French Polynesia Laboratoire d'Excellence "CORAIL", Perpignan, France 
Viliame Waqalevu

Laboratoire d'Excellence "CORAIL", Perpignan, France

Laboratory of Larval Rearing Management, United Graduate School of Agricultural

Sciences, Kagoshima University, Japan

School of Marine Studies, University of the South Pacific, Suva, Fiji

vwaqalevu@hotmail.com

\author{
Alain Siu \\ Bora-Bora Island Escape, Bora-Bora, French Polynesia \\ admin@ircp.pf
}

\title{
Tamatoa Bambridge
}

PSL University, EPHE-UPVD-CNRS, USR 3278 CRIOBE, 98729 Moorea, French Polynesia

The Rahui Forum and Resource Center, Tahiti, French Polynesia

tamatoa.bambridge@criobe.pf

\begin{abstract}
Understanding the natural state of coral reefs is paramount to evaluate the response of these ecosystems to local and global human impacts as well as management and conservation strategies. In French Polynesia, some islands are still pristine or uninhabited, such as Tupai atoll. Tupai has been uninhabited, with access to the lagoon prohibited since 2010. However, fishers from nearby islands often take from the outer reef slope at Tupai. Our marine biodiversity survey (coral, macro-invertebrates, and fish) conducted in 2019 highlighted a low density of commercial fish species and top-predators on the outer slope in comparison to the lagoon, where the top-predators represented 16\% (of the density) of functional trophic groups. Our surveys also showed a high living coral cover (46\%) on the outer slope of Tupai, perhaps due to the absence of both touristic sub-aquatic activities and local pollution from private and commercial activities. Overall, this initial scientific assessment of Tupai has granted an understanding of the spatial patterns of coral, macro-invertebrates, and fish assemblages in the absence of human impacts (i.e., in the lagoon), representing an ecological baseline that could inform conservation management strategies to ensure the preservation of coral reef ecosystem.
\end{abstract}

Keywords: conservation actions, coral reef, ecological baselines, French Polynesia, marine biodiversity, pristine island, Tupai atoll

https://doi.org/10.24043/isj.150 • Received June 2020, accepted February 2021

(C) Island Studies Journal, 2021

\section{Introduction}

Insularity has long been recognized as a pressure cooker for evolution, with several renowned examples of endemism and extinction of marine and terrestrial island species (Baldacchino, 
2006). MacArthur and Wilson (1967) state that "the island is the first unit that the mind can pick out and begin to comprehend." Faced with the rampant anthropization of terrestrial and marine habitats across the planet, pristine or uninhabited islands permit a unique insight into what constitutes a natural state for an environment (Knowlton \& Jackson, 2008). Moreover, pristine/uninhabited islands are often hotspots of biodiversity and are also rich in endemic species (Kier et al., 2009) and can act as conservation refuges from threats affecting mainland populations (Gibson et al., 2017). Lastly, since early 2020 and the start of the COVID-19 pandemic, many studies have investigated the impacts of the restrictions of human activities in frequented places, particularly touristic islands (e.g., Buckley, 2020; Rutz et al., 2020; Zambrano-Monserrate et al., 2020), in order to better understand how tourism and fishing in particular affect the biodiversity, ecology, and economy of these socio-ecosystems. However, most studies lack real controls (i.e., pristine/uninhabited islands) that may serve as references for what "human free" ecosystems may look like. Unfortunately, biodiversity inventories for pristine/uninhabited islands are often opportunistic and lack continuity and thoroughness due to the logistical and financial challenges of implementing long-term monitoring (Meyer et al., 2015).

Although the coral islands are often far from the major capitals of the world, anthropogenic impacts still strongly degrade coral reefs worldwide (e.g., Hughes et al., 2017; Moritz et al., 2018; Morrison et al., 2019). Over the past four decades, the effects of global climate change (such as acidification or temperature rise) and other local anthropogenic pressures (such as wastewater or plastics) have led to the definitive loss of at least $20 \%$ of the world's coral reefs, with the remainder increasingly at risk (Hughes et al., 2017; Morrison et al., 2019). For example, sedimentation or terrestrial run-off, due to either hotel construction or intensive agriculture, could kill corals (Fabricius, 2005). Tourism also has the potential to be a major cause of coral reef degradation through activities where humans come into direct contact with the reef and its inhabitants, such as boating, fish feeding, diving, and snorkeling (Rouphael \& Inglis, 2001), as well as indirectly as a result of coastal development or resource extraction (e.g., Hawkins \& Roberts, 1992; Tratalos \& Austin, 2001; Siriwong et al., 2018). Yet, coral reefs support several essential environmental and socioeconomic processes (e.g., food production, tourism, biotechnology, and coastal protection) for many island nations, such as those within the South Pacific (Costanza et al., 2014; Hoegh-Guldberg, 2015; Moritz et al., 2018). In French Polynesia, 42 of the 118 coral islands are still pristine or uninhabited, allowing scientists to study coral reefs that have not been affected by major local anthropogenic changes. Tupai atoll is one of these pristine/uninhabited islands.

Tupai atoll $\left(16^{\circ} 15^{\prime} 03.0^{\prime \prime} \mathrm{S} ; 151^{\circ} 47^{\prime} 48.6^{\prime \prime} \mathrm{W}\right)$ is located $275 \mathrm{~km}$ north-west of Tahiti and $15 \mathrm{~km}$ north-north-west of Bora-Bora, in the Society Islands archipelago. Tupai is a small atoll (950 ha, $24 \mathrm{~km}$ in circumference, $6 \mathrm{~km}$ at its greatest width [W-E], $8 \mathrm{~km}$ at its greatest length [N-S]; Andréfouët et al., 2005) with an exceptionally closed lagoon, with only $3 \%$ of the length of the reef external boundary open to the ocean beyond. There are no large passages into the lagoon and only five functional $h \bar{o} \bar{a}$ (small channels between the lagoon and the ocean). Tupai atoll, formerly sparsely inhabited by three Polynesian families, was rediscovered by Europeans during the first voyage of James Cook to French Polynesia, on July 27, 1769. In 1930, thirty people lived on northwest of the atoll and used the area as a coconut plantation. By 1983, the population on Tupai had risen to 50 people (Grant, 1986). In 1998, the Polynesian government bought the atoll as a touring site for notable guests. In 2010, the atoll became uninhabited following cyclone Oli, which destroyed the three existing 
fare (traditional houses made from wood and coconut leaves) and the small private airport runway. In 2004, Tupai was claimed by the indigenous movement Ia Faahoi te fenua a te nuanaa ("May the land be given back to the people") as ancestral lands. Although unsuccessful, this movement demonstrated the concern of the indigenous people of the Society Islands for the future of Tupai. Since 2010, three Polynesian government guards have been monitoring the atoll (Butaud, 2011). Therefore, Tupai can be considered an uninhabited atoll with a near pristine coral reef lagoon (i.e., unaffected by local human impacts), as the only constructions ever to enter the lagoon were the wooden stilts of the fare. It is worth noting that although access to the lagoon has been prohibited since 2010 (with restrictions enforced by government guards), the outer slope at Tupai is often fished by fishermen from Bora-Bora and Raiatea.

Historic scientific field trips to Tupai include an archaeological study by Ropiteau (1962); several botanical studies by Grant (1937), Sachet (1983), and Butaud (2011); avifaunal studies by Thibault and Thibault (1973) and Butaud (2011); and a geomorphology study by Pirazzoli et al. (1985). No marine biodiversity surveys had been conducted at Tupai prior to this study. We found only a short description of substrate in Pirazzoli et al. (1985): dominance in coral genera of Pocillopora, Acropora, and Porites on the outer slope and reef flat, and of Acropora and Porites in the lagoon; no quantitative data are given in the report. Our field trip was conducted in November 2019 in order to describe the spatial patterns of coral, macroinvertebrates, and fish assemblages in the absence of human impacts (i.e., in the lagoon), and thereby obtain an ecological baseline (Sandin et al., 2008). Furthermore, this first comprehensive coral reef ecosystem survey lays the foundation for future monitoring programs at Tupai and will provide some fundamental insights into the conservation and restoration efforts of coral reefs in French Polynesia.

\section{Materials and methods}

\section{Marine biodiversity survey}

In 2019, a team of researchers from the Centre de Recherches Insulaires et Observatoire de l'Environnement (CRIOBE) conducted a four-day field trip to survey eight habitats at Tupai: outer slope, reef flat, hōā, brackish pool (i.e., ponds of salty water within the islet (motu) which collect rainwater, and sometimes seawater in periods of strong swell or winds), northern patch reef, central patch reef, southern patch reef, and western patch reef (see Figure 1). For each habitat, 3-4 sites were chosen and two transect replicates were set up per site. On each transect ( $20 \mathrm{~m}$ long $\mathrm{x} 5 \mathrm{~m}$ wide), the substrate types (i.e., living coral, dead coral with algal turf, coral rubble, coral slab, macroalgae, sand, and muddy sand) were recorded every metre using the point intercept transect method (Lecchini \& Galzin, 2005). The macroinvertebrates (all species) and fish (all species and two ontogenetic stages: adult and juvenile; Lecchini \& Galzin, 2005) were recorded using underwater visual census surveys along the same transect within a $5 \mathrm{~m}$ wide tunnel $\left(100 \mathrm{~m}^{2}\right.$ total) and in two successive passes for fish. On the first pass, the observer recorded highly mobile fishes that entered the transect but usually fled with a diver's approach. On the second pass, less mobile and site-attached species were recorded. Fishes were categorized into four functional trophic groups, as suggested by Friedlander et al. (2010), and using diet parameters obtained from FishBase (www.fishbase.org): primary consumers (herbivores, detritivores, and corallivores), secondary 
consumers (planktivores and benthivores [benthic carnivores]), and tertiary consumers (apex predators and other piscivores).

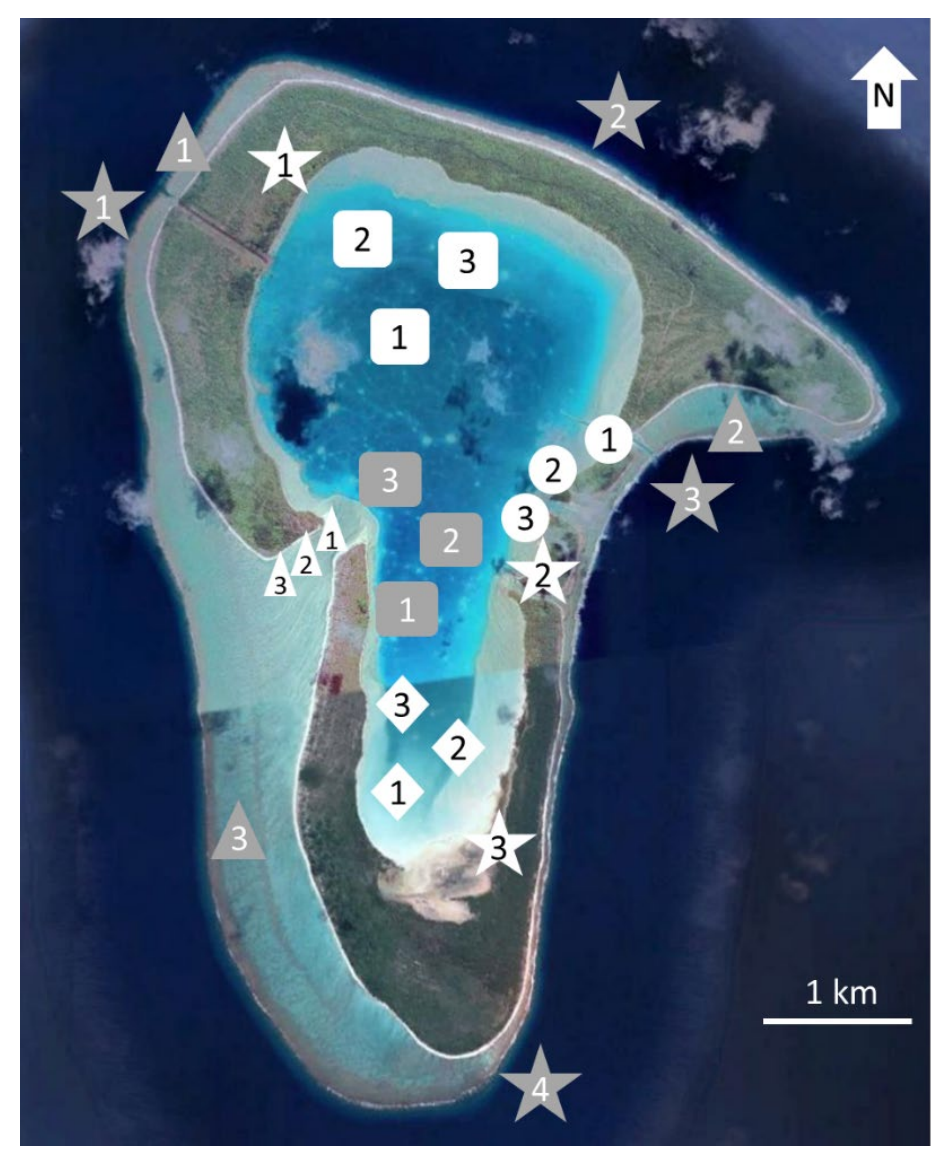

Figure 1. Map of Tupai Atoll with the location of the different habitats surveyed in the lagoon and on the outer slope. For each habitat, 3-4 sites were chosen and two transect replicates were set up per site. The symbols for each habitat are as follows: grey stars $=$ outer slope, grey triangles $=$ reef flats, white circles $=$ hōā, white squares $=$ north patch reefs, grey squares $=$ central patch reef, white diamonds $=$ south patch reefs, white triangles $=$ west patch reefs, and white stars $=$ brackish pools. The arrow indicates North (symbol 'N').

\section{Data analysis}

The number of transects was constrained by the time available to sample different replicates for all the habitats. Two transects were conducted per site (instead of three transects as usual) but biodiversity surveys could be conducted on several sites per habitat: 4 sites on the outer slope, 3 sites on the reef flat, 3 sites on the hōā, 3 sites on the northern patch reef, 3 sites on the central patch reef, 3 sites on the southern patch reef, 3 sites on the western patch reef, and 3 sites on the brackish pool. Thus, the analyses were conducted at the habitat level with a total of at least 6 transects per habitat.

The spatial distribution of substrate cover was calculated from counts of the number of each substrate type for each habitat type per transect, i.e., outer slope, reef flat, hōā, northern patch reef, central patch reef, southern patch reef, western patch reef, and brackish pool. Following our first observations of the coral reefs at Tupai, we considered that there was no difference on the external slope between the different coasts (similar habitat: non-parametric Kruskal-Wallis tests between the four outer slope sites, $\mathrm{P}>0.05)$. On the other hand, due to 
the quality and the turbidity of water in the lagoon, the patch reefs were differentiated in the lagoon between North and South. The normal distribution of each substrate type was tested with Shapiro-Wilk tests $(W=0.63-0.93$, all $\mathrm{P}$ values $<0.05)$ and differences between habitats were tested by means of non-parametric Kruskal-Wallis tests, followed by Dunn's multiple comparisons tests if significant differences were found.

Likewise, the density (i.e., the number of individuals per $100 \mathrm{~m}^{2}$ ) of macro-invertebrates $(W=0.49-0.84$, all $\mathrm{P}$ values $<0.05)$ and fishes $(W=0.61-0.92$, all $\mathrm{P}$ values $<0.05)$, were compared between habitats by means of non-parametric Kruskal-Wallis tests followed by Dunn's multiple comparisons tests. All statistical analyses were conducted using R-Studio (R version 3.6.3) with a significance level $\alpha=0.05$.

\section{Results}

Spatial distribution of substrate cover

The habitats significantly differed in their substrate composition (Figure 2). The brackish pools were solely composed of muddy sand, while the western patch reefs had the most heterogeneous distribution with different substrate types (e.g., from $5.8 \pm 3.4 \%$ of macroalgae to $26.7 \pm 12.6$ $\%$ of dead coral and $23.3 \pm 5.4 \%$ of coral rubble). Except in brackish pools, the living coral cover on the outer slope was $46.5 \pm 0.8 \%$ and significantly higher than on the reef flat, the hōā, and the northern patch reefs which displayed the lowest cover with $5 \pm 0.2 \%$ (KruskalWallis, $\chi_{6}^{2}=30.26, \mathrm{P}<0.001 ;$ Dunn tests, $\mathrm{Z}=3.09-4.66$, all $\mathrm{P}$ values $<0.05$ ) (Figure 2). All habitats in the lagoon were dominated by representatives from the genus Porites (ranging from $53 \%$ to $93 \%$ of total living coral cover). On the outer slope, Pocillopora genus dominated ( $76 \%$ vs. $12 \%$ for Porites and $8 \%$ of Acropora). The outer slope contained significantly less coral rubble $(3.1 \pm 1.9 \%)$ than the reef flat $(44.2 \pm 9.7 \%)$, hōā $(50.0 \pm 6.7 \%)$, and the central patch reefs $(45.0 \pm 7.2 \%)$ (Kruskal-Wallis, $\chi^{2}{ }_{6}=29.11, \mathrm{P}<0.001$; Dunn tests, $\mathrm{Z}=3.57-$ 4.07 , all $\mathrm{P}$ values $<0.05)$. Reef flats and the southern patch reefs $(43.3 \pm 6.7 \%$ and $39.2 \pm$ $9.2 \%$ respectively) had significantly more coral slab than the central patch reefs $(0.8 \pm 0.8 \%)$ (Kruskal-Wallis, $\chi^{2}{ }_{6}=28.95, \mathrm{P}<0.001$; Dunn tests, $\mathrm{Z}=3.42-3.95$, all $\mathrm{P}$ values $<0.05$ ) (Figure 2). Lastly, the macro-algae cover dominated on the northern patch reefs $(49.17 \pm 7 \%)$ and was significantly higher than on reef flats $(0.8 \pm 0.8 \%)$ and in hōā $(1.7 \pm 1.7 \%)$ (KruskalWallis, $\chi_{6}^{2}=25.44, \mathrm{P}<0.001$; Dunn tests, $\mathrm{Z}=3.82-4.27$, all $\mathrm{P}$ values $<0.05$ ) (Figure 2). No differences were found in the dead coral cover and sand cover between habitats. 


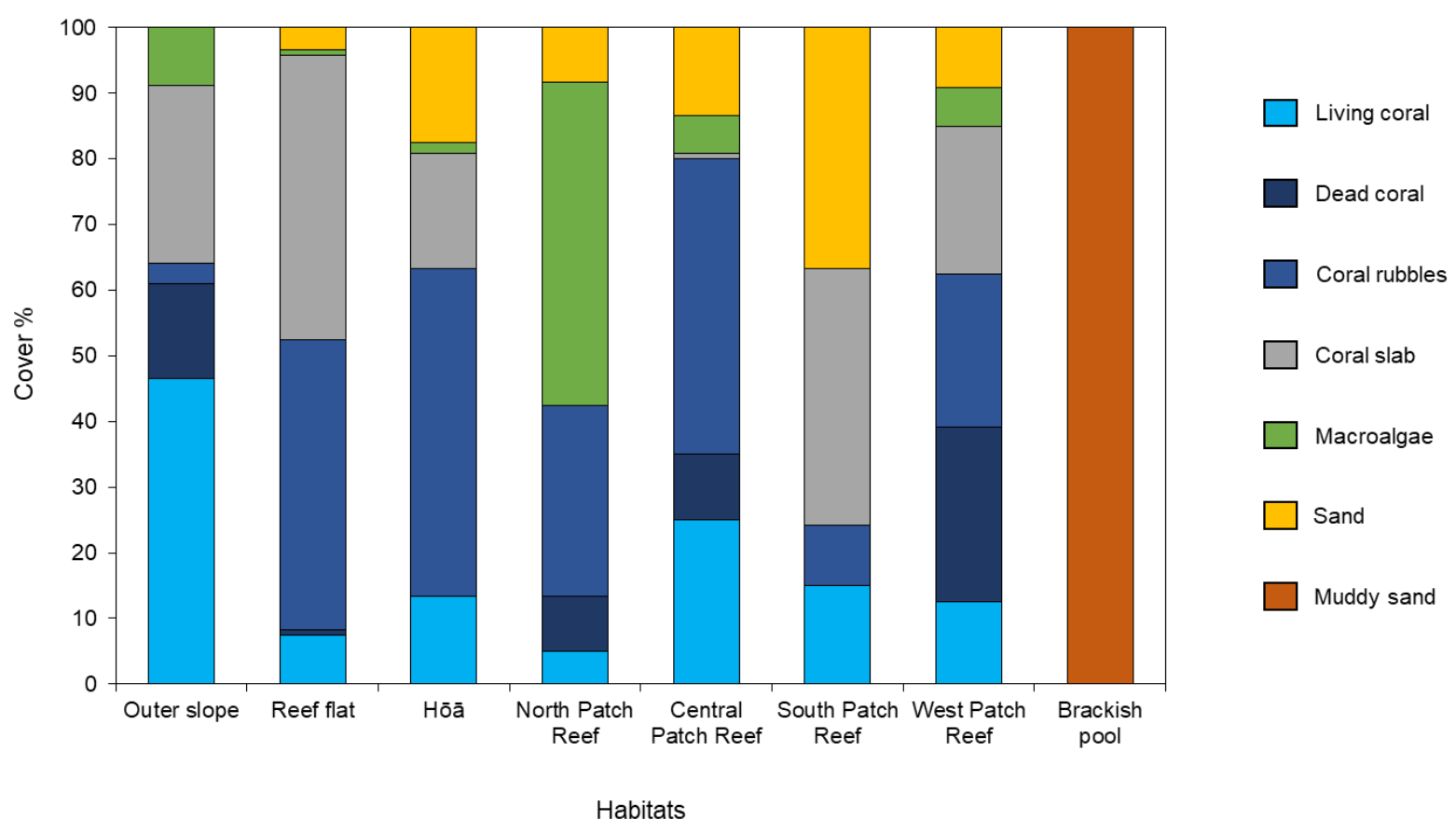

Figure 2. Percentage of substrate cover (i.e., living coral, dead coral with algal turf, coral rubbles, coral slab, macroalgae, sand, and muddy sand) recorded on the different habitats (i.e., outer slope, reef flat, hōā, northern patch reef, central patch reef, southern patch reef, western patch reef, and brackish pool) at Tupai in 2019.

\section{Spatial distribution of macro-invertebrates}

The macro-invertebrate community varied significantly according to habitat (Figure 3 ). The reef flats were dominated by giant clams Tridacna maxima $\left(30.6 \pm 3.7\right.$ individuals per $\left.100 \mathrm{~m}^{2}\right)$ which were significantly more abundant than in the northern patch reefs $(0.3 \pm 0.02$ individuals per $\left.100 \mathrm{~m}^{2}\right)$ and southern patch reefs $\left(1.7 \pm 0.9\right.$ individuals per $\left.100 \mathrm{~m}^{2}\right)$ (KruskalWallis, $\chi_{3}^{2}=7.98, \mathrm{P}=0.046$; Dunn tests, $\mathrm{Z}=2.00-2.23$, all $\mathrm{P}$ values $<0.05$ ) (Figure 3). Giant clams were absent from the other habitats. Hōā and the western patch reefs were dominated by sea-cucumbers (respectively, $4.3 \pm 1.2$ individuals per $100 \mathrm{~m}^{2}$ and $15.6 \pm 1.8$ individuals per $100 \mathrm{~m}^{2}$ ). These two habitats showed no significant differences in sea-cucumber abundance (Kruskal-Wallis, $\chi_{3}{ }_{3}=12.28, P=0.006$; Dunn test, $\mathrm{Z}=2.27, \mathrm{P}=0.09$ ) (Figure 3). The western patch reefs had a significantly higher abundance of sea-cucumbers than the two other habitats in which sea-cucumbers were found, i.e., the reef flats (Dunn test, $\mathrm{Z}=$ $2.89, \mathrm{P}=0.02$ ) and the central patch reefs (Dunn test, $\mathrm{Z}=2.58, \mathrm{P}=0.04$ ). The main species of sea-cucumber present was a non-commercial species, Holothuria atra. The other commercial species, i.e., Holothuria fuscogilva, H. whitmaei, Thelenota ananas, Bohadschia argus, and Actinopyga mauritiana, were rare, with densities of $<0.001$ individuals per $100 \mathrm{~m}^{2}$. The northern, central, and southern patch reefs were dominated by ark clams, Arca ventricosa $(0.5 \pm 0,1.2 \pm 0.9$, and $3.5 \pm 1.5$ individuals per $100 \mathrm{~m}^{2}$, respectively). No significant differences were found between these habitats (Kruskal-Wallis, $\chi^{2}{ }_{3}=4.15, \mathrm{P}=0.24$ ). The outer slope was dominated by green turbans, Turbo marmoratus (1.6 \pm 0.4 individuals per $100 \mathrm{~m}^{2}$ ), which were not found elsewhere. Sea-urchins, which were mainly Diadema savignyi and Echinometra mathaei, were only present on reef flats $\left(1.3 \pm 0.8\right.$ individuals per $\left.100 \mathrm{~m}^{2}\right)$, the central patch reefs $(0.3 \pm 0$ individuals per $\left.100 \mathrm{~m}^{2}\right)$ and the outer slope $\left(0.1 \pm 0\right.$ individuals per $\left.100 \mathrm{~m}^{2}\right)$ and showed no differences in 
abundance between sites (Kruskal-Wallis, $\chi_{2}^{2}=2.40, \mathrm{P}=0.30$ ). Lastly, the densities of all other macro-invertebrates (not shown in Figure 3) were low $\left(<0.001\right.$ individuals per $\left.100 \mathrm{~m}^{2}\right)$, including: Ophiuroidea (mainly Ophiocoma schoenleinii), Asteroidea (mainly Acanthaster planci and Culcita novaeguineae), Terebridae (mainly, Terebra maculata), Strombidae (mainly Lambis truncata), Spondylidae (Spondylus varius), and Chamidae (Chama isotoma).

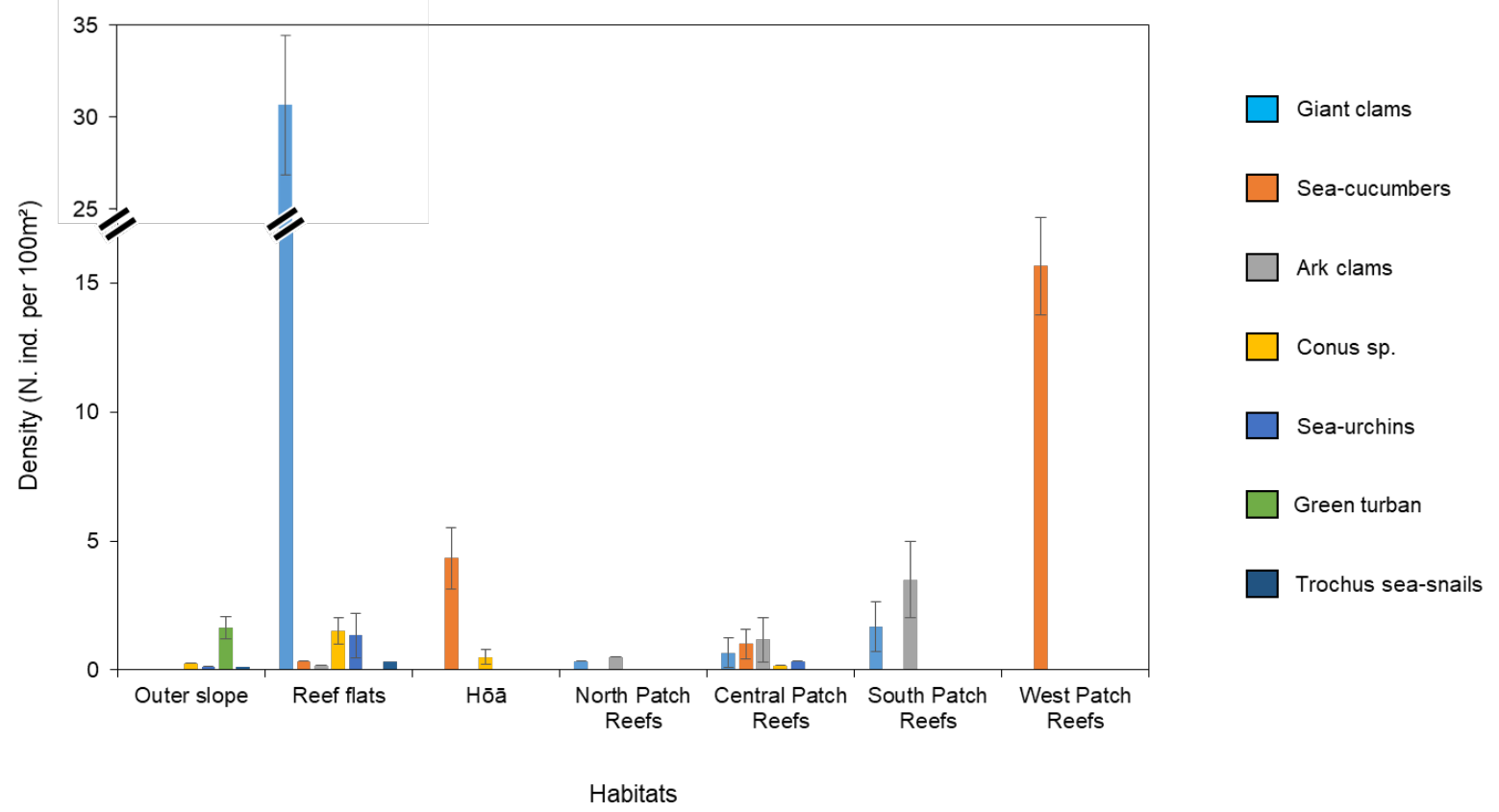

Figure 3. Density (number of individuals per $100 \mathrm{~m}^{2}$ ) of the main macro-invertebrates (i.e., giant clams, sea-cucumbers, ark clams, Conus sp., sea-urchins, green turbans, and Trochus sea-snails) recorded on the different habitats. Values are mean \pm SD. No invertebrates were counted in the brackish pools.

Spatial distribution of coral reef fish

The density of fish varied significantly according to habitat for both juvenile stage (Kruskal-Wallis, $\chi^{2}{ }_{7}=24.86, \mathrm{P}<0.001$ ) and adult stage (Kruskal-Wallis, $\chi_{7}^{2}=34.35, \mathrm{P}<0.001$ ) (Figure 4). The highest densities of juveniles were found on the central and west patch reefs with 150.8 \pm 5.0 individuals and $107.2 \pm 10.2$ individuals per $100 \mathrm{~m}^{2}$, respectively. The density of juveniles was significantly lower on the southern patch reefs $\left(8.5 \pm 2.3\right.$ individuals per $\left.100 \mathrm{~m}^{2}\right)$ than on outer slopes, central patch reefs, western patch reefs, and reef flats (Dunn tests, $Z=$ $2.69-3.59$, all $\mathrm{P}$ values < 0.05) (Figure 4). The highest species richness of juveniles was found on reef flats and central patch reefs with 27 and 37 different species, respectively. The least rich habitats were the southern patch reefs and brackish pools with 9 and 3 different species, respectively. The western patch reefs and outer slopes showed the highest densities of adults with $184.8 \pm 8.1$ individuals per $100 \mathrm{~m}^{2}$ and $128.4 \pm 3.2$ individuals per $100 \mathrm{~m}^{2}$, respectively. The lowest density of adults was found in brackish pools with $16.7 \pm 6.2$ individuals per $100 \mathrm{~m}^{2}$, which was significantly lower than the densities observed on outer slopes, central, and western patch reefs (Dunn tests, $Z=3.00-3.79$, all $\mathrm{P}$ values $<0.05$ ) (Figure 4). The highest species richness of adult fishes was found on outer slopes and reef flats with 48 and 47 different species, respectively. The least rich habitat was the brackish pools with only 2 different species observed. 
Among the 126 species recorded at the adult stage, there were 37 commercial species. The highest densities were found on western patch reefs $\left(97.8 \pm 13.2\right.$ individuals per $\left.100 \mathrm{~m}^{2}\right)$ and reef flats $\left(26.2 \pm 2.4\right.$ individuals per $\left.100 \mathrm{~m}^{2}\right)$. The density of commercial species on western patch reefs was significantly higher than in hōā and northern patch reefs (KruskalWallis, $\chi_{7}^{2}=27.44, \mathrm{P}<0.001$; Dunn tests, $\mathrm{Z}=3.08-3.29$, all $\mathrm{P}$ values $<0.05$ ). On the outer slope, the density of fish was low $\left(11.9 \pm 0.9\right.$ individuals per $\left.100 \mathrm{~m}^{2}\right)$ despite the species richness being the highest (48 species). Among the 1126 adult fish of commercial species recorded (27\% of the total adult population), the five most abundant species were: Lutjanus fulvus (Lutjanidae: $45 \%$ of the total commercial species population), Myripristis violacea (Holocentridae: 7\%), M. adusta (Holocentridae: 7\%), Chlorurus spilurus (Scaridae: 6\%), and Acanthurus guttatus (Acanthuridae: 6\%). Lastly, no commercial species at the adult stage were found in brackish pools. However, the juveniles in this habitat were almost exclusively commercial species in high density (i.e., Albula glossodonta, Chanos chanos).

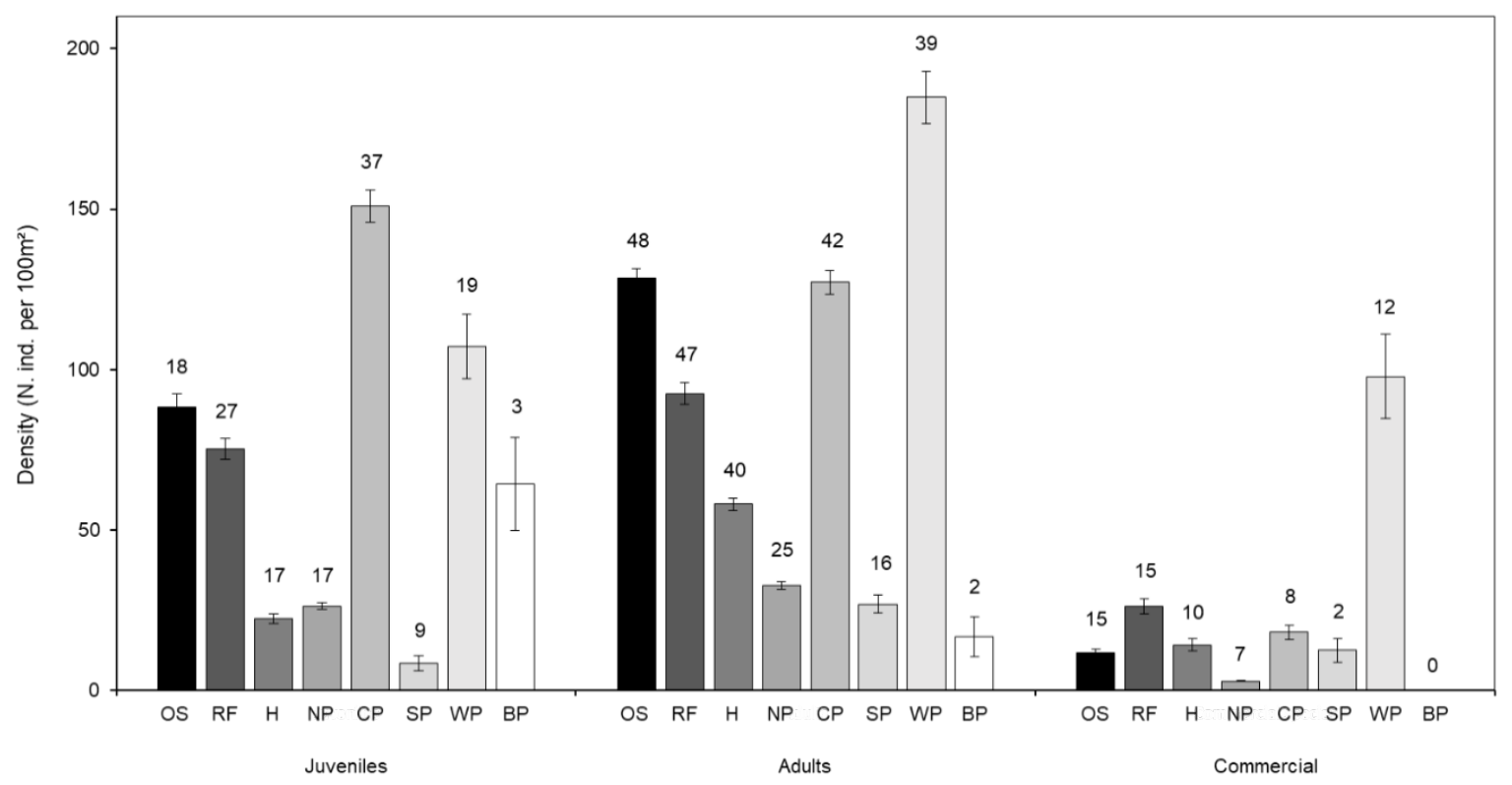

Figure 4. Density (number of individuals per $100 \mathrm{~m}^{2}$ ) of coral reef fish at juvenile and adult stages and of commercial species recorded on the different habitats $(\mathrm{OS}=$ outer slopes, $\mathrm{RF}=$ reef flats, $\mathrm{H}=\mathrm{Hōa}, \mathrm{NP}=$ northern patch reefs, $\mathrm{CP}=$ central patch reefs, $\mathrm{SP}=$ southern patch reefs, $\mathrm{WP}=$ western patch reefs, and $\mathrm{BP}=$ brackish pools). Values are mean $\pm \mathrm{SD}$. Numbers on top of bars indicate the total number of species.

The analysis of trophic groups (Figure 5) showed a dominance of primary consumers (herbivores, detritivores, and corallivores) in the lagoon (62\% of total fish density) and on the outer slope (45\%). The tertiary consumers (apex predators and other piscivores) had the second highest density in the lagoon (16\%), but the lowest one on the outer slope (1\%). The main tertiary consumers were Lutjanus fulvus (blacktail snapper) and Caranx melampygus (bluefin jack). Surprisingly, there were very few sharks (only 5 recorded - black tip sharks and nurse sharks) in the lagoon despite preventing fishermen from entering the lagoon. 


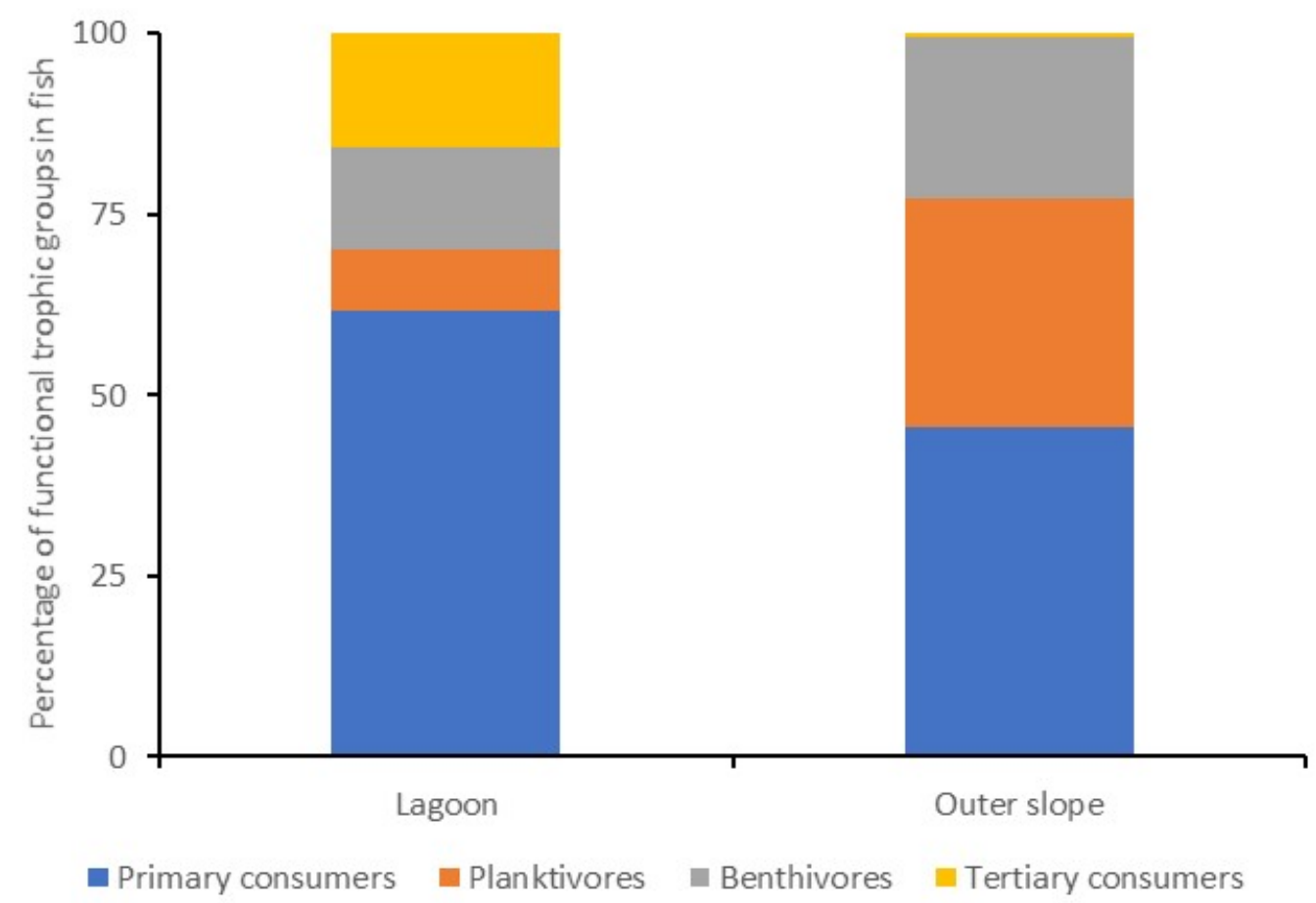

Figure 5. Proportion (\%, calculated on density data) of fish in each of the four functional trophic groups (i.e., primary consumers, planktivores, benthivores, and tertiary consumers) found on the outer slope and in the lagoon.

\section{Discussion}

In their research comparing pristine and anthropized reefs, Sandin et al. (2008) showed that two pristine reefs, Kingman and Palmyra in the northern Line Islands, support a fish assemblage dominated by top predators, a benthic assemblage composed largely of reefbuilding coralline algae and corals, and clear water with only limited microbial abundance. In contrast, two nearby anthropized islands, Kiritimati and Tabuaeran, support reefs with greatly reduced fish mass and fewer large fish predators, and with a higher abundance of fleshy algae and microbes (see also Friedlander \& DeMartini, 2002; DeMartini et al., 2008; Friedlander et al., 2010). However, this tendency to have a healthy coral reef and greater diversity and abundance of fish on pristine/remote islands compared to anthropized islands cannot be generalized everywhere in the world (Bradley et al., 2017). The marine biodiversity of an island depends on many biogeographic, geomorphologic, and ocean current parameters (e.g., Williams, 1991; Ruppert et al., 2017). Furthermore, it is always difficult to compare two islands, even close ones, due to physicochemical and oceanographic variations that can occur on small spatial scales (e.g., Galzin, 1987; Planes et al., 2012; Hedouin et al., 2020). Nevertheless, a better understanding of marine biodiversity can be gleaned from these islands' comparisons, especially with pristine/remote islands on which long term monitoring is rare (Meyer et al., 2015). In our study, the biodiversity of the coral reefs around Tupai will be compared with Bora-Bora, the closest island to Tupai (Gabrie et al., 1994).

Lecchini et al. (in press) conducted similar surveys in 2019 inside the anthropized BoraBora lagoon. The living coral cover at Bora-Bora ranged from 26\% (fringing reef) to $42 \%$ (patch reef). At Tupai, the living coral cover inside the lagoon ranged from 5\% (northern 
patch reefs) to $25 \%$ (central patch reefs). All habitats within the lagoon were dominated by representatives from the genus Porites (ranging from 53\% to $93 \%$ of total living coral cover). Pirazzoli et al. (1985) showed also a dominance in coral genera of Acropora and Porites in the lagoon. The coral reefs inside the lagoon were less healthy at Tupai, despite it being an uninhabited island, compared to Bora-Bora which receives 120,000 tourists per year (Blondy, 2016). A potential reason for this might be the lack of water circulation in the lagoon at Tupai. With only 5 functional hōā, the water is rarely renewed and the northern part of the lagoon is permanently subjected to an algal bloom (Landret, 1976). This algal bloom and the lack of clear water would also explain the high coverage of macroalgae on the north patch reefs. The low densities of the main macro-invertebrate taxa $(0.3$ sea-urchins, 6 giant clams, and 2 sea-cucumbers per $100 \mathrm{~m}^{2}$ ) could also be explained by the lack of renewal of the lagoon's water and a resulting lack of oxygen. Moreover, as observed for some reefs in the world over the last 20 years, mass mortality of sea-urchins could have occurred at Tupai due to bacterial or viral disease outbreaks (Sweet et al., 2016; Muthiga \& McClanahan, 2020). As observed by Pirazzoli et al. (1985), the mollusks were dominated by giant clams in the lagoon. Lastly, the living coral cover is high (46\%) on the outer slope at Tupai (for data of other French Polynesia Islands from SO Coral Observatory, see http://observatoire.criobe.pf) potentially due to the absence of human disturbance (e.g., SCUBA diving) and local pollution from homes and businesses (e.g., terrestrial runoff).

At Bora-Bora, the highest density of fish was 98 adults and 62 juveniles per $100 \mathrm{~m}^{2}$. Among the 105 species recorded at the adult stage, there were 32 commercial species (Lecchini et al., in press). At Tupai, the highest densities of adults were found on the western patch reefs and outer slope $\left(184.8 \pm 8.1\right.$ individuals and $128.4 \pm 3.2$ individuals per $100 \mathrm{~m}^{2}$, respectively) and on central and western patch reefs for juveniles (150.8 \pm 5.0 individuals and $107.2 \pm 10.2$ individuals per $100 \mathrm{~m}^{2}$, respectively). Among the 126 species recorded the adult stage, there were 37 commercial species found. The highest densities were observed on western patch reefs $\left(97.8 \pm 13.2\right.$ individuals per $\left.100 \mathrm{~m}^{2}\right)$. These results are consistent with previous findings that pristine/uninhabited reefs are often hotspots of biodiversity (e.g., Sandin et al., 2008; DeMartini et al., 2008; Gilson et al., 2017; Ferretti et al., 2018). The habitats with the highest levels of biodiversity (in terms of fish and macro-invertebrates) at Tupai were the central and western patch reefs. Notably, these habitats also reside in the path of the lagoon's water current which, with the predominance of easterly winds, flows from the hōa located in the northeast to the hōa located in the southwest. The outer slope is characterized by a low density but high species richness of commercial species. Lastly, only $1 \%$ of fish were tertiary consumers (large snappers, groupers, jacks) on the outer slope, while within the lagoon, especially on central and western patch reefs, $16 \%$ of fish were tertiary consumers. These results are consistent with the pattern of protection of the reef at Tupai, with higher densities of fish and increased levels of biodiversity observed in the lagoon where access is prohibited, compared to lower densities of fish observed on the outer slope which is visited by fishermen from Bora-Bora and Raiatea (Butaud, 2011). 


\section{Conclusion}

With Tupai being close to touristic islands such as Bora-Bora, Tahaa, and Raiatea, some recreational activities could be developed there in the future. However, there are often significant negative correlations between diving activity and coastal biodiversity on coral reefs (e.g., Hawkins \& Roberts, 1992; Hawkins et al., 1999; Tratalos \& Austin, 2001). Nevertheless, Cerda et al. (2017) underlined that tourists prefer high ecological quality, with a higher value placed on ecosystems when multiple species are protected, rather than selected charismatic species (see also Hausmann et al., 2017). Thus, Tupai could be developed into a marine reserve with a strong biodiversity conservation outcome. This would require limitations on the number of tourists per day, and for the profits generated to fund conservation of Tupai's coral reefs. Another potential strategy for protecting Tupai is the creation of a fully protected area covering the lagoon and the outer slope, implemented by the government of French Polynesia (known as the rāhui system; Bambridge, 2016). This highlights the challenges faced in preserving environments in an ever-changing world, particularly in locations where fishing and tourism are important parts of life for local communities. Whatever the future of Tupai holds, our study provides the island's first ecological baseline and thus will allow a greater understanding of the impacts of future changes, such as ecotourism or protected areas, on ecosystem structure and biodiversity.

\section{Declaration of competing interest}

The authors declare that they have no known competing financial interests or personal relationships that could have appeared to influence the work reported in this paper.

\section{Acknowledgments}

We thank the three Polynesian government guards to their help during this expedition. Service d'Observation CORAIL from CRIOBE kindly provided coral data on the French Polynesian Islands other than Tupai (http://observatoire.criobe.pf/). The expedition and the writing of the paper were supported by the French Polynesia Government and by several funders: Fondation de France (2019-08602), Ministère de l'Economie verte et du domaine Délégation à la recherche de Polynésie française (contrat N3622 MED-EPHE), LabEx CORAIL (projects 2018 Emul and 2019 Plasti-Perl), ANR-19-CE34-0006-Manini, and the Rāhui Forum and Resource Center supported by Bloomberg's Philanthropy.

\section{References}

Andréfouët S., Chauvin C., Spraggins S., Torres-Puzilla D., \& Kranenbourg C. (2005). Atlas des récifs coralliens de Polynésie française. Centre IRD de Nouméa.

Baldacchino, G. (2006). Islands, Island Studies, Island Studies Journal. Island Studies Journal, 1(1), 3-18.

Bambridge, T. (2016). The Rāhui. Australian National University Press. 
Blondy, C. (2016). Le tourisme, un facteur de développement durable des territoires insulaires tropicaux? Tourisme, aménagement, environnement et société locale à Bora Bora (Polynésie française). Mondes $\quad d u \quad$ Tourisme, $\quad 1, \quad 8-19$. https://doi.org/10.4000/tourisme.1283 Kendall, B. E., Gaines, S. D., \& Caselle, J. E. (2017). Resetting predator baselines in coral reef ecosystems. Scientific Reports, 7, 43131. https://doi.org/10.1038/srep43131

Buckley, R. (2020). Conservation implications of COVID19: Effects via tourism and $\begin{array}{llll}\text { extractive industries. Biological Conservation, 247, } 108640 . & \end{array}$

https://doi.org/10.1016/j.biocon.2020.108640

Butaud, J. F. (2011). Flore, formations végétales, faune et enjeux de conservation de l'atoll de Tupai (Iles sous le Vent). Service du Développement Rural \& Direction de l'Environnement.

Cerda, C., Fuentes, J. P., Luz de la Manza, C., Louit, C., \& Araos, A. (2017). Assessing visitors' preferences for ecosystem features in a desert biodiversity hotspot. Environmental Conservation, 1, 1-8. https://doi.org/10.1017/s0376892917000200

Costanza, R., de Groot, R., Sutton, P., der Ploeg, S., Anderson, S. J., Kubiszewski, I., Farbere, S., \& Turner, K. (2014). Changes in the global value of ecosystem services. Global Environmental Change, 26, 152-158. https://doi.org/10.1016/j.gloenvcha.2014.04.002

DeMartini, E. E., Friedlander, A. M., Sandin, S. A., \& Sala, E. (2008). Differences in fish assemblage structure between fished and unfished atolls in the northern Line Islands, central Pacific. Marine Ecology Progress Series, 365, 199-215. https://doi.org/10.3354/meps07501

Fabricius, K. E. (2005). Effects of terrestrial runoff on the ecology of corals and coral reefs: Review and synthesis. Marine Pollution Bulletin, 50, 125-46. https://doi.org/10.1016/j.marpolbul.2004.11.028

Ferretti, F., Curnick, D., Liu, K., Romanov, E. V., \& Block, B. A. (2018). Shark baselines and the conservation role of remote coral reef ecosystems. Science Advances, 4, eaaq0333. https://doi.org/10.1126/sciadv.aaq0333

Friedlander, A. M., \& DeMartini, E. E. (2002). Contrasts in density, size, and biomass of reef fishes between the northwestern and the main Hawaiian islands: The effects of fishing down apex predators. Marine Ecology Progress Series, 230, 253-264. https://doi.org/10.3354/meps230253

Friedlander, A. M., Sandin, S. A., DeMartini, E. E., \& Sala, E. (2010). Spatial patterns of the structure of reef fish assemblages at a pristine atoll in the central Pacific. Marine Ecology Progress Series, 410, 219-231. https://doi.org/10.3354/meps08634

Gabrie, C., Planes, S., Baldwin, J., Bonvallot, J., Chauvet, C., Vernaudon, Y., Payri, C., \& Galzin, R. (1994). Study of the coral reefs of Bora-Bora (Society Archipelago, French Polynesia) for the development of a conservation and management plan. Ocean Coastal Management, 25, 189-216. https://doi.org/10.1016/0964-5691(94)90056-6

Galzin, R. (1987). Structure of fish communities of French Polynesian coral reefs. I. Spatial scales. Marine Ecology Progress Series, 41, 129-136. https://doi.org/10.3354/meps041129 
Gibson, L. A., Cowan, M. A., Lyons, M. N., Palmerc, R., Pearsonc, D. J., \& Doughty, P. (2017). Island refuges: Conservation significance of the biodiversity patterns resulting from 'natural' fragmentation. Biological Conservation, 212, 349-356. https://doi.org/10.1016/j.biocon.2017.06.010

Grant, M. L. (1986). Journal in the Society Islands (1930-1931). Previously unpublished manuscript prepared by Dorothy Grant.

Grant, M. L. (1937). Flora of a coral atoll, Society Islands. American Journal of Botany, 24, 742-751.

Hausmann, A., Slotow, R., Fraser, I., \& Di Minin, E. (2017). Ecotourism marketing alternative to charismatic megafauna can also support biodiversity conservation. Animal Conservation, 20, 91-100. https://doi.org/10.1111/acv.12292

Hawkins, J. P., \& Roberts, C. M. (1992). Effects of recreational SCUBA diving on fore-reef slope communities of coral reefs. Biological Conservation, 62, 171-178. https://doi.org/10.1016/0006-3207(92)91045-t

Hawkins, J. P., Roberts, C. M., \& Van't Hof, T. (1999). Effects of recreational scuba diving on Caribbean coral and fish communities. Conservation Biology, 13, 888-897. https://doi.org/10.1046/j.1523-1739.1999.97447.x

Hedouin, L., Rouzé, H., Berthe, C., \& Planes, S. (2020). Contrasting patterns of mortality in Polynesian coral reefs following the third global coral bleaching event in 2016. Coral Reefs, 39, 939-952. https://doi.org/10.1007/s00338-020-01914-w

Hoegh-Guldberg, O. (2015). Reviving the ocean economy: The case for action - 2015. WWF World Wide Fund For Nature. https://www.worldwildlife.org/publications/revivingthe-oceans-economy-the-case-for-action-2015

Hughes, T. P., Kerry, J. T., \& Álvarez-Noriega, M. (2017). Global warming and recurrent mass bleaching of corals. Nature, 543, 373-377.

Kier, G., Kreft, H., Lee, T. M., Jetz, W., Ibisch, P. L., Nowicki, C., Mutke, J., \& Barthlott, W. (2009). A global assessment of endemism and species richness across island and mainland regions. Proceeding National Academy Sciences, 106, 9322-9327. https://doi.org/10.1073/pnas.0810306106

Knowlton, N., \& Jackson, J. B. C. (2008). Shifting baselines, local impacts, and global change on coral reefs. PLoS Biology, 6, e54. https://doi.org/10.1371/journal.pbio.0060054

Landret, J. P. (1976). Rapport de mission effectuée à Tupai le 23 novembre 1976: "Etude d'un phénomène d'eaux rouges le dimanche 20 novembre 1976 ». Contrat COP-CNEXONaturalia et Biologia études de sites.

Lecchini, D., \& Galzin, R. (2005). Spatial repartition and ontogenetic shifts in habitat use by coral reef fishes (Moorea, French Polynesia). Marine Biology, 147, 47-58. https://doi.org/10.1007/s00227-004-1543-z

Lecchini, D., Bertucci, F., Schneider, D., Berthe, C., Gache, C., Fogg, L., Waqalevu, V., Maueau, T., Sturny, V., Bambridge, T., \& Tong Sang, G. (in press). Bora-Bora: The forgotten island. Regional studies in marine science. Elsevier.

MacArthur, R. H., \& Wilson, E. O. (1967). The theory of island biogeography. Monographs in population biology, no. 1. Princeton University Press.

Meyer, C., Kreft, H., Guralnick, R., \& Jetz, W. (2015). Global priorities for an effective information basis of biodiversity distributions. Nature Communications, 6, 8221. https://doi.org/10.1038/ncomms9221 
Moritz, C., Vii, J., Lee Long, W., Tamelander, J., Thomassin, A., \& Planes, S. (Eds.). (2018). Status and trends of coral reefs of the Pacific. Global Coral Reef Monitoring Network (GCRMN).

Morrison, T. H., Hughes, T. P., Adger, W. N., \& Brown, K. (2019). Save reefs to rescue all ecosystems. Nature, 573, 334-336. https://doi.org/10.1038/d41586-019-02737-8

Muthiga, N. A., \& McClanahan, T. R. (2020). Diadema, sea urchins: Biology and ecology. Development Aquatic Fisheries Sciences, 43, 397-418. https://doi.org/10.1016/b978-0_ 12-819570-3.00023-8

Pirazzoli, P., Brousse, R., Delibrias, G., Montaggioni, L. F., Sachet, M. H., Salvat, B., \& Sinoto, Y. H. (1985). Leeward Islands (Maupiti, Tupai, Bora Bora, Huahine), Society archipelago. In B. Delesalle, R. Galzin, \& B. Salvat (Eds.), Proceedings of the fifth International Coral Reef Congress Tahiti, vol. 1: French Polynesian coral reefs (pp. 15-72). Antenne Museume-Ephe. https://doi.org/10.1007/bf00301196

Planes, S., Lecchini, D., Mellin, C., Charton, J. G., Harmelin-Vivien, M., Kulbicki, M., Mou-Tham, G., \& Galzin, R. (2012). Environmental determinants of coral reef fish diversity across several French Polynesian atolls. Comptes Rendus Biologies, 335, 417423. https://doi.org/10.1016/j.crvi.2012.04.002

Ropiteau, A. (1962). Quelques informations concernant les marae de Tupai. Bulletins de la société des études océaniennes, 139(12), 81-85.

Rouphael, A. B., \& Inglis, G. J. (2001). "Take only photographs and leave only footprints"? An experimental study of the impacts of underwater photographers on coral reef dive sites. Biological Conservation, 100, 281-287. https://doi.org/10.1016/s00063207(01)00032-5

Ruppert, J. L. W., Vigliola, L., Kulbicki, M., Labrosse, P., Fortin, M. J., \& Meekan, M. G. (2017). Human activities as a driver of spatial variation in the trophic structure of fish communities on Pacific coral reefs. Global Change Biology, 24, 44-52. https://doi.org/10.1111/gcb.13882

Rutz, C., Loretto, M.-C., Bates, A. E., Davidson, S. C., Duarte, C. M., Jetz, W., Johnson, M., Kato, A., Kays, R., Mueller, T., Primack, R. B., Ropert-Coudert, Y., et al. (2020). COVID-19 lockdown allows researchers to quantify the effects of human activity on wildlife. Nature Ecology and Evolution, 4, 1156-1159. https://doi.org/10.1038/s41559_ 020-1237-z

Sachet, M. H. (1983). Botanique de l'île de Tupai, Iles de la Société. Atoll Research Bulletin, 276, 1-26. https://doi.org/10.5479/si.00775630.276.1

Sandin, S. A., Smith, J. E., DeMartini, E. E., \& Dinsdale, E.A. (2008). Baselines and degradation of coral reefs in the northern Line Islands. PLoS ONE, 3, e1548. https://doi.org/10.1371/journal.pone.0001548

Siriwong, S., True, J. D., \& Piromvarakorn, S. (2018). Number of tourists has less impact on coral reef health than the presence of tourism infrastructure. Songklanakarin Journal of Science and Technology, 40, 1437-1445.

Sweet, M., Bulling, M., \& Williamson, J. E. (2016). New disease outbreak affects two dominant sea urchin species associated with Australian temperate reefs. Marine Ecology Progress Series, 551, 171-183. https://doi.org/10.3354/meps11750 
David Lecchini et al.

Thibault, B., \& Thibault, J. C. (1973). Rapport ornithologique sur l'atoll Tupai - îles de la Société. Office de la recherche scientifique et technique outre-mer (ORSTOM), antenne de Tahiti.

Tratalos, J. A., \& Austin, T. J. (2001). Impacts of recreational SCUBA diving on coral communities of the Caribbean island of Grand Cayman. Biological Conservation, 102, 67-75. https://doi.org/10.1016/s0006-3207(01)00085-4

Williams, D. Mc. B. (1991) Patterns and processes in the distribution of coral reef fishes. In P. F. Sale (Ed.), The ecology of fishes on coral reefs (pp. 437-474). Academic Press New York. https://doi.org/10.1016/b978-0-08-092551-6.50021-0

Zambrano-Monserrate, M. A., Ruano, M. A., \& Sanchez-Alcalde, L. (2020). Indirect effects of COVID-19 on the environment. Science of the Total Environment, 728(1), 138813. https://doi.org/10.1016/j.scitotenv.2020.138813 